\title{
Canadian Multicultural Paradigm: Research Methodology
}

\author{
Natalia A. Pestushko* \\ Khabarovsk State Institute of Culture \\ 112 Krasnorechenskaia Str., Khabarovsk, 680045, Russia
}

Received 12.03.2016, received in revised form 19.04.2016, accepted 26.05.2016

\begin{abstract}
Research methodology is an important component of any scientific work. Until recently, the Russian cultural studies had no specific research dealing with complex methods of scientific analysis of the Canadian model of multiculturalism. Meanwhile, the successful implementation of Canadian policy, aimed at the preservation and enrichment of cultural differences, not only points to the importance of studying the Canadian multicultural paradigm, but also to the need to consider the possibilities of using the Canadian experience in Russia. This work pursues the aim of studying the methods of scientific analysis of the Canadian multicultural paradigm and the factors behind its choice.
\end{abstract}

Keywords: multiculturalism, cultural policy, interethnic interaction, methodology, modeling, hermeneutics.

DOI: 10.17516/1997-1370-2016-9-6-1490-1498.

Research area: culture studies.

\section{Introduction}

One of the distinguishing features of the modern world has been a marked increase in the level of negative connotation in cross-cultural relations. This fact is largely a consequence of the boosted civilizational interaction in the second half of the $20^{\text {th }}$ century gain and, as a consequence, the separation of cultures on the dominant and adaptable ones. In the process of expansion of cross-cultural contacts and the emergence among individual nations of a need to adapt to the norms of a foreign cultural environment there became even more vivid ethnocultural differences and incompatibility of cultural traditions. Homogenous in their core concept countries (mainly European - author's note) were not ready to build a heterogeneous society, which should be based on a variety of ethnic and cultural groups.

Alongside with that, despite the growth of cross-cultural and inter-ethnic conflicts, individual states could successfully put into practice the principles of cultural integration, creating a truly heterogeneous society in which there are no xenophobia and intolerance, while ethnic contradictions are resolved peacefully. One of these countries is Canada, where in the early 1970s the government adopted a policy of multiculturalism aimed at resolving the contradictions between French-speaking and

(c) Siberian Federal University. All rights reserved

* Corresponding author E-mail address: nataliapestushko@gmail.com 
English-speaking communities of this country (Kolodii, 2004), as well as at preservation and supporting the cultural traditions of other ethnic groups.

An analysis of the conceptual foundations of the Canadian model of multiculturalism and its features, as well as identifying opportunities for the use of the Canadian experience in Russia are of great scientific interest. A study of the Canadian multicultural paradigm, consideration of scientific and ideological components of this phenomenon, the analysis of the causes of the Canadian multicultural model's success involves resort to the written in English primary sources (laws, regulations), the materials of the Russian and Canadian media, scientific literature in Russian and Western European languages.

An integral part of any study is a methodology or set of scientific methods for analysis. The scientific method means a well-ordered way of action concentrated on achieving a specific practical or theoretical purpose (Ruzavin, 2012, p. 4). The choice of methods and techniques of any scientific study is determined by goals and objectives of the work, as well as by primary sources and special literature, which are used for the coverage of the topic. The correct choice of research method largely presupposes the final result, either success or failure in the task implementation.

Until recently, the Russian cultural studies had virtually no special works, which would analyze the research methodology of the Canadian multicultural paradigm. The authors of most of the works dealing with this issue made only a list of general scientific and specific methods used for casting light on the topic of research (Balickaia, 2008, pp. 6-7; Zhukov, 2013; Tashmetova, 2008, p. 9). Nevertheless, a simple indication of the methods does not always make it possible to form a correct idea of how these methods are connected with the study, its goals and objectives.
In addition, purely ascertaining approach in considering the methodological basis of scientific research does not reveal how involved techniques have helped in achieving the goals stated.

In the present study the author attempted to examine the complex scientific methods used in the study of the Canadian multicultural paradigm, as well as to analyze the factors that led to the methodology selection.

\section{Methods of study of the Canadian model of multiculturalism}

Before we proceed directly to consideration of the methodology of study of the Canadian multicultural model it is necessary to give a general description of the methods of the cultural scientific analysis and the research methods used in the analysis of multicultural systems. In cultural studies researchers use scientific methods that are part of the general humanities. In particular, they include a combination of methods, including observation, evaluation of the researched phenomenon, validation of the data, integrating the results of one's own investigation into the general scientific theory.

As a branch of cultural studies research, multiculturalism has a comprehensive super-branch character. The study of the multiculturalism policy is not limited to the sphere of cultural sciences, but is based on a multidisciplinary approach. This approach involves the use of research results from related disciplines - ethnology, sociology, history, political science, philosophy and linguistics. Interdisciplinary status of multiculturalism as a scientific problem is caused by, inter alia, the diversity and the contradictory positions of the researchers who regarded this issue, as well as by various manifestations of the multicultural policy (Tolerantnost' $\mathrm{v}$ sovremennom mire, 2011, p. 315). Thus, the research methodology of the multicultural paradigm is composed of general 
scientific and specific methods, which allows one to consider multicultural policy and its regional characteristics in an ample way, involving scientific methods from related disciplines.

Review of the research methodology of the Canadian multiculturalism model is advisable to start with an analysis of "the universal or almost universal" dialectic method (Ruzavin, 2012, p. 8), which observes the establishment and development of any cultural system not only as a sequence of continuous transformations, but also taking into account the possibility of the new cultural types' emergence as a result of social fluctuations.

With regard to Canada and established in this country model of multicultural policy, our use of the dialectical method gives us the opportunity to analyze the cultural and historical features of the development of Canadian society, as well as on the basis of the identified features to predict the way of the evolution of the Canadian multiculturalism in the future. In particular, today's discussion of the possibilities of introducing new cultural traditions and practices in the existing in Canada legal framework suggests a significant expansion of the boundaries of the multiculturalism policy in this country.

Similar problems can be solved by the modeling method (Ushakov, 2005, pp. 142144). The goal of this method is to identify the distinguishing characteristics of the studied cultural system, the laws of its development for some time and the prediction based on the results of cross-cultural processes and ethnic interactions. Despite the fact that the concept of the model refers to the number of philosophical and scientific categories, it can be attributed also to the categories of cultural studies, as a method of "cultural interpretation of reality" (Sanzheeva, 2011, p. 196).

The simulation (modeling) method allows us to reconstruct a multicultural society and the processes of cross-cultural and interethnic interactions in the form of logic, graphics, and databases. As a model of society and its crosscultural processes can be, for example, ethnic groups with their own traditions, customs and ethics. In contrast to the above discussed dialectical method, modeling method is characterized by a more accurate prediction of the socio-cultural processes, since it takes into account more factors and statistical data.

Construction of the studied cultural object (Canadian multiculturalism) as a model, including the ethnic core of integrating cultural factors that are responsible for the preservation of cultural identity (language, traditions, religion, living area), representatives of the minorities, as well as data showing the proportion of carriers of traditional Canadian culture and migrants, not only objectively assess the actual effectiveness of Canadian multiculturalism, but also more accurately predict the future of cross-cultural processes in the country.

Consideration of the characteristics of the policy of multiculturalism involves the use of the structural-functional method, based on the study of the structure of a particular cultural system and the identification of interdependencies between its basic elements (language, social norms, religion) (Belik, Berger, 1999). In particular, with reference to the problems of the Canadian multiculturalism the structural-functional method is necessary for the cultural and linguistic analysis of the language situation in Canada, where the language environment is characterized by a unique co-existence of a large number of languages (aboriginal languages, languages of the immigrant population, the so-called "hybrid" languages, and also official French and English).

Language is the main means of human knowledge of the world and the main means of cross-cultural communication. The language of any ethnic group is inseparable from its 
culture. For this reason, any external influence on the cultural environment inevitably affects the language. On the one hand, one of the main indicators of the individual's adaptation to the new ethno-cultural environment is the termination of use of the native language (Savel'ev, 1997: 9). At the same time, this statement is only partially true. The language change indicates the transition to the different cultural environment, often meaning abandoning the old system of values, religious beliefs, etc. By the way, the continued use of their mother tongue and the language of a new cultural environment is not an obstacle for the integration of the individual into a foreign culture. On the contrary, the policy of multiculturalism involves not only the preservation of traditional cultural values, but also the original mother tongue. In particular, since the 1960s Canada has supported cultural minority languages at the national and regional levels, while the English and French languages have had the status of official languages. In other words, the Canadian model of multiculturalism implies the absence of the homogeneous cultural and linguistic space as a necessary condition of national unity (Zaika, 2010, p. 3).

All of this means that without the use of the structural-functional method it is impossible to create a complete picture of multicultural interactions in the contemporary Canadian society and to identify the impact of the Canadian cultural environment and accepted in Canadian society social norms on the culture of immigrants, their native language and traditional beliefs.

The method of cultural analysis and synthesis should also be applied; it is understood as a set of scientific methods, aimed at a comprehensive understanding of the essence of culture and the construction of the complex idea of it. The method of analysis and synthesis is used in cultural studies, as it has a general cultural and philosophical basis, due to the interdisciplinary nature of cultural sciences (Sokolova, 2006, pp. 73-75).

In the context of the multicultural Canadian society study, the method of analysis and synthesis is needed to study the degree of variability in the fundamental characteristics of the "nonCanadian" cultures within the boundaries of the common cultural space. The investigated characteristics should primarily include the traditional beliefs, customs, language, food and culture, etc. Identification of the impact of culture on integrating these factors, as well as the analysis of the stability of integrable cultures against the background of outside influence allows us to have a general idea of how the ethnic minorities can maintain (lose) their original cultural environment, and to get a notion about the multicultural Canadian system as a whole (Sokolov, 2007).

Studying features of the Canadian model of multiculturalism led to the use of the genetic method of research, involving consideration of the history and formation of this or that social and cultural phenomenon. Despite the fact that Canada is a country of immigrants, only two ethnic groups - the English-Canadians and French-Canadians play the first fiddle in the crosscultural interactions in Canadian society, as they represent more than $70 \%$ of the population. Thus, in contrast to many other multicultural paradigms, the Canadian model is characterized by a dualistic primordial preset, due to the coexistence of the two ethnic groups - the English and French within a single socio-cultural space (Rex, Singh, 2003, p. 11). Historically at the level of interethnic interactions Canadian cultural dualism has always had a negative connotation. The foregoing is thanks to the policy of assimilation, which the British colonialists in Canada carried out in respect of the French-speaking population, the reluctance of the British colonists to considered the French as equals, and finally, for the most 
part, due to the formal bilingual policy of the British administration.

Thus, the genetic method is necessary to identify the relationship between historically rooted negative basis of Anglo-French crosscultural interaction and modern "Quebec separatism", as well as to predict the crosscultural processes in Canadian society better.

There are also scientific methods of cultural studies, which, as a rule, have no analogues in other disciplines. These methods should include the immersion method, aimed at identifying the links between people and their object-cultural environment (Chuklina, 2011). Unlike many other disciplines related to cultural studies, such as philosophy, political science, sociology, the attention to the peculiarities of another culture and the factors determining these features suggests plunging into the subject of research, i.e. in a different culture, a deep awareness of the factors causing peculiarities of this cultural system.

The method of "immersion" in the area of Canadian culture is a prerequisite for the formation of cultural competence, for creating a balance between the researchers' own cultural environment and culture of Canada, for identifying the distinctive characteristics, inherent to both socio-cultural systems. In the context of the study of Canadian multicultural paradigm, the method of "immersion" allows the researchers to maintain constant contact with the Canadian culture and its forming factors. This makes possible not only to give an objective assessment of the characteristics of the studied cultural system, but also to be more aware of their own cultural environment, to evaluate the chance of using the Canadian unrivalled experience in creation of the multicultural heterogeneous society in Russian conditions.

The scientific work of the cultural orientation, pursuing the analysis of cross-cultural and interethnic interactions, have traditionally used methods of field research (Vasil'ev, 2002, p. 40). Polls of target groups of respondents for identifying their relationship to the need to preserve the cultural identity, ethnic diversity, multicultural policy of the host state, enable researchers to give an accurate and objective estimation of the cross-cultural processes in the society.

Study of the processes of cross-cultural interactions by using questionnaires and interviews is essential for the comprehensive research of the multicultural paradigm in Canada. In particular, the methods of field studies are needed to identify the role of acculturation, which plays a significant role in facilitating inter-ethnic relations in Canadian, as it is mutual exchange of traditions and cultural traits. Acculturation is the interpenetration of cultural systems, in which the level of interaction between the dominant cultures and the integrable one does not reach the level of cultural assimilation (Tatarko, 2009, pp. 63-90).

The very notion of a "multiculturalism policy" determines the methods of investigation. As a complex phenomenon, multiculturalism involves a variety of factors that are directly related to it, i.e. the languages of cross-cultural communication, semantics and personal cultural parameters, which interact with each other, and the social and historical evolution of cultural systems and their structural features.

At the same time, the comparative nature of multiculturalism as a scientific phenomenon, as well as fairly broad subject area of the methodological approach of modern cultural studies (Sokolova, 2006, pp. 73-75) indicate the need for the simultaneous use of several scientific methods. So, theanalysis ofmulticultural paradigm with consistent use of diachronic, synchronic and comparative methods makes it possible to analyze the time sequence of the processes of cross-cultural interactions, compare the stages 
of interpenetration of different cultural systems over time, as well as to trace in diachronically essential change of factors that make up a single multicultural complex - anthropology, cultural symbolism, historical dynamics, etc.

One of the features of modern Canada is a quite high level of cultural diversification, owing to the large area of the country and the population division along the territorial and ethnic lines. This separation took place before the appearance of the first Europeans in Canada, when the majority of Canadian society was made up of autochthonous tribes of Indians and Inuits. With the advent of the French settlers to Canada in the $16^{\text {th }}$ century, cultural differences began to show themselves at the level of the colonists and the indigenous tribes. In the $17-18^{\text {th }}$ centuries together with the growth of rivalry between France and Britain for supremacy in Canadian, cultural differences reached the level of opposed British and French cultural traditions. Further development of the cultural identity of Canadian society took place against the contempt of cultural traditions of the indigenous population, the increase in the flow of Europeans to Canada and the mutual separation of the cultural traditions of the British and French colonists, which in the early 1960s became the socalled "problem of Quebec separatism" (SorokoCjupa, 1985, pp. 4-13; Rex, Singh, 2003, p. 11).

Thus, given the history of Canada and the specifics of the modern Canadian culture, the consistent application of above-mentioned three methods will be essential to the diachronic analysis of the formation and evolution of the Canadian multicultural paradigm and its constituent factors.

The system method, used in the analysis of a multicultural society, allows one to study objects of culture as a system. Any of the "difficult" subjects of culture consists of system elements that are relatively independent units (Drach, Davidovich, 2003, p. 62). As scientific approach the system method is designed to show united and indivisible nature of culture. This task is achieved by referring to certain cultural types and their constituent elements, identifying the characteristics of integrable cultures and conditions that ensure the connection stability of the cultural types with each other within the limits of united cultural field. In addition, the system method can take advantage of the results of studies related to cultural studies, such as philosophy, sociology, political science.

Multicultural policy is systemic in nature, regardless of the country, in which it is applied. Multiculturalism as a socio-cultural phenomenon affects many spheres of human activity, such as education, arts, social and political movements. In other words, getting an objective idea of the inter-ethnic processes in this or that country, or successful resolution of cross-cultural issues largely depend on how specific cultural factors, making up united cultural system, exhaustively investigated. For example, it is necessary to take into account the possibility of the existence of ethnic groups, whose culture and beliefs can not only be disapproved by a majority, but also they can contradict the very foundations of the host cultural environment (Kukatas, 2007). In this case, the Canadian multiculturalism model is no exception and also requires a systematic approach in the analysis of individual cultural types, as well as in the identification of factors responsible for successful socialization of representatives of other cultures in Canadian society.

We should also focus on the use of the hermeneutic method. In a broad sense, hermeneutics is the science dealing with the historical and philological interpretation of texts (Ushakov, 2005, p. 338). As an epistemological method of interpreting texts, including "sacred" texts (the Bible, the Quran, the Kojiki, etc.), hermeneutics came with the emergence of writing. 
Today the main task of hermeneutics is not confined to the methodological focus on comprehension of the meaning. Its goal is to identify the "ontological status of understanding as a moment of human life" (Slovar' filosofskikh terminov, 2005, p. 103). Thus, nowadays the research area of hermeneutics is not limited to written texts and ancient manuscripts, but also can act as a tool for scientific analysis of the human being and the corresponding cultural components. Itshouldbeborneinmind that culture as a type of human communication is a symbolic and significant event. Any cultural phenomenon is a symbolic system that has semantic meaning. The iconic cultural characteristics include the language of communication, traditional rites, ceremonies, folklore, and traditional beliefs. The above characteristics are the language of culture, including socially significant information, which indicates the need for the hermeneutic method in cultural studies.

Using the hermeneutical method in the research of the Canadian multicultural paradigm enables us to focus on the cultural component of interethnic communication. As a part of the hermeneutic method the subject of direct research is a representative of another culture, who moved to Canada. The researchers are to study the changing motives of behavior, values, cognitive motivation under the influence of the Canadian cultural environment. As a consequence, the hermeneutical method helps to identify personality changes of a representative from integrable culture in interaction with the cultural realities of Canada, and also allows for analysis of the transformation of their ethnic self-identity. Being applied to the Canadian multiculturalism model the hermeneutical method may reveal the level of transformation of the cultural code of integrable ethnic group as a whole on the example of some cultural changes. So the researcher can achieve a high level of accuracy in determining the conditions for the harmonious coexistence of different cultures and in facilitating crosscultural forecasting processes.

\section{Conclusion}

The correct choice of research methods ultimately determines the outcome of any research and objectivity of the conclusions of its author. The consideration of instruments of scientific knowledge used in cultural studies, as well as in the Canadian multicultural paradigm research allows us to state the following. The authors of scientific papers on cultural studies widely use scientific methods, which are used in other disciplines. Along with them, the researchers apply narrower methods unique to cultural studies. This fact is explained by the fact that cultural studies are interdisciplinary in nature and use the results of many studies from related fields of scientific knowledge.

Analysis of the research methodology of the Canadian multiculturalism proves that any of the above listed methods will work efficiently only with some goals and objectives. In other words, none of the discussed methods of scientific knowledge cannot be attributed to a number of universal methods. Only the integrated use of these methods, in addition to taking into account the characteristics of Canadian culture, which is so unique due to the high level of heterogeneity in the Canadian society, is critical for a comprehensive analysis of the multicultural policy in this country.

\section{References}

Balitskaia, I.V. (2008). Mul'tikul'turnoe obrazovanie v SShA, Kanade i Avstralii [Multicultural education in the USA, Canada and Australia]. Moscow, $30 \mathrm{p}$. 
Belik, A.A., Berger, Ia.M. (1999). Kul'turologiia. Uchebnoe posobie [Culturology. Textbook], available at: http://sbiblio.com/biblio/archive/baxmin_berger_kulturology/ (accessed 23 May 2015).

Chuklina, T.I. (2011). Metod pogruzheniia kak aktual'nyi metod postroeniia muzeinoi ekspozitsii [Immersion method as a modern method of constructing a museum exhibition]. SaintPetersburg, $182 \mathrm{p}$.

Drach, G.V., Davidovich, V.E., \& Erygin, A.N. (2003). Kul'turologiia [Culture studies]. Moscow, Al'fa-M, 432 p. Available at: http://yanko.lib.ru/ann/culturology-drach-2003-a.htm (accessed 6 June 2015).

Kolodii, A. (2004). The Idea and Diverse Reality of Multiculturalism: Are They Applicable to Newly Independent States? Available at: http://political-studies.com/english/political/multiculturalism. html (accessed 6 June 2015).

Kukatas, Ch. (2007). Teoreticheskie osnovy mul'tikul'turalizma [Theoretical foundations of multiculturalism]. Available at: http://polit.ru/article/2007/05/27/multiculturalism/ (accessed 6 June 2015).

Rex, J., Sing, G. (2003). Multiculturalism and Political Integration in Modern Nation-States: Thematic Introduction, In International Journal on Multicultural Societies, 1, Vol. 5, 3-19.

Ruzavin, G.I. (2012). Metodologiia nauchnogo poznaniia [Methodology of scientific knowledge]. Moscow, Juniti-Dana, 287 p.

Sanzheeva, L.V. (2011). Modelirovanie kul'tury: perspektivy issledovaniia [Culture modeling], In Obshhestvo. Sreda. Razvitie (Terra Humana) [Society. Environment. Development (Terra Humana)], (3),196-198.

Savel'ev, I.R. (1997). Iapontsy za okeanom. Istoriia iaponskoi emigratsii v Severnuiu i Iuzhnuiu Ameriku [Japanese overseas. The history of the Japanese emigration to North and South America]. Saint-Petersburg, Center "Peterburgskoe vostokovedenie", 224 p.

Slovar' filosofskikh terminov [Dictionary of philosophical terms]. 2005. Moscow, INFRA-M, $731 \mathrm{p}$.

Sokolov, V.I. (2007). Kanada: poisk natsional'noi identichnosti putem sozdaniia mnogokul'turnogo obshchestva [Canada: search for national identity by creating multicultural society], In Prostranstvo i vremia v mirovoi politike i mezhdunarodnykh otnosheniiakh: materialy 4 Konventa RAMI [Space and time in the world politics and international relationship: proceedings of the $4^{\text {th }}$ Convent RAMI], 2. Moscow, MGIMO-Universitet, 108-114.

Sokolova, I.B. (2006). Fenomenologicheskii podkhod k analizu proizvedenii kul'tury [Phenomenological approach to the analysis of works of culture]. Kul'turologicheskie issledovaniia. Saint-Petersburg, Asterion, 73-75.

Soroko-Cjupa, O.S. (1985). Istoriia Kanady: Uchebnoe posobie dlia studentov vuzov, obuchaiushchikhsia po special'nosti "Istoriia" [History of Canada: Textbook for university students, who study History as major]. Moscow, Vysshaia shkola, $304 \mathrm{p}$.

Tashmetova, Sh.E. (2008). Sovremennaia etnokul'tura megapolisov Kanady: v kontekste mul'tikul'turalizma [Modern ethnic culture inCanadian megalopolises: in multiculturalism context]. Moscow, 20 p.

Tatarko, A.N. (2009). Metodologiia i metodika issledovaniia akkul'turatsii i mezhkul'turnogo vzaimodeistviia [Methodology and research techniques of acculturation and cross-cultural 
interaction], In Strategii mezhkul'turnogo vzaimodeistviia migrantov i naseleniia Rossii [Strategies of cross-cultural interaction of migrants and Russian population]. Moscow, Rossiiskii universitet druzhby narodov, 63-90.

Tolerantnost' $v$ sovremennom mire: opyt mezhdistsiplinarnykh issledovanii: sbornik nauchnykh statei [Tolerance in modern world: experience of interdisciplinary research: collection of scientific papers]. (2011).Yaroslavl, JaGPU, 357 p.

Ushakov, E.V. (2005). Vvedenie v filosofiu i metodologiiu nauki: Uchebnik [Introduction in scientific philosophy and methodology: Textbook]. Moscow, Ekzamen, 528 p.

Vasil'ev, M.I. (2002). Vvedenie v kul'turnuiu antropologiiu [Introduction in Cultural anthropology]. Velikii Novgorod, Novgorod State University "Yaroslav-the-Wise", 156 p.

Zaika, K.V. (2010). Problema natsional'noi integratsii $v$ usloviiakh vozrastaiushchego etnokul'turnogo mnogoobraziia (na primere Kanady) [Problem of national integration in the conditions of increasing ethnic and cultural diversity (on the example of Canada)]. Moscow, $26 \mathrm{p}$.

Zhukov, D.S. (2013). Kvebekskii faktor evoliutsii partiino-politicheskoi sistemy Kanady v kontse $X X-n a c h a l e X X I v v$. [Quebec evolution factor of party and political system in Canada at the end of the 20th-beginning of the 21st centuries]. Moscow, $173 \mathrm{p}$.

\section{Канадская мультикультурная парадигма: методология исследования}

Н.А. Пестушко Хабаровский государственный институт культуры Россия, 680045, Хабаровск, ул. Краснореченская, 112

\footnotetext{
Методология исследования является важной составляющей любой научной работы. До недавнего времени в российской культурологии не было специальных исследований, в которых бы комплексно рассматривались методы научного анализа канадской модели мультикультурализма. Между тем успешная реализация Канадой политики, направленной на сохранение и взаимообогащение культурных различий, указывает не только на важность изучения канадской мультикультурной парадигмы, но также на необходимость рассмотрения возможностей использования канадского опыта в России. Представленная работа преследует иелью изучение методов научного анализа канадской мультикультурной парадигмы и факторов, обусловивших их выбор.
}

Ключевые слова: мультикультурализм, культурная политика, межэтническое взаимодействие, методология, моделирование, герменевтика.

Научная специальность: 24.00.00 - культурология. 